\title{
On the People-oriented Management
}

\section{of Higher Vocational Students}

\author{
Yan Feng \\ Chongqing Business Vocational College, Chongqing, 400036
}

\begin{abstract}
According to the requirements of scientific development, we should adhere to the student-oriented principle, integrate management with training of higher vocational students and establish the studentoriented educational idea through renewing managing thoughts when we conduct the people-oriented management of higher vocational students. We should also strive to improve the management mechanism and set up humanitarian operation system. Meanwhile, the task includes the science and art of people-oriented management and the efficient training mechanism of harmonious campus for healthy human development. All of these efforts are aiming at the mutual promotion and common development of talent training, school development and social harmony.
\end{abstract}

Keywords: people-oriented, higher vocational college, student management

The higher vocational college plays the role of major basis for training highquality professional talents and a crucial component of Chinese higher education. As the most fundamental project, the student management of higher vocational college is the basic guarantee for realizing educational objective. Consequently, the student management should fulfill the requirements of scientific development, adhere to the people-oriented idea, reform and innovate the thoughts, methods and mechanism of student management and strengthen the humanistic management on campus.

\section{The contents of people-oriented management of higher vocational students}

The people-first concept belongs to Chinese splendid ideological heritage, and the organic components of advanced socialist culture. Required by the third plenary session of the 16th central committee of Chinese communist party, all the construction work of the party and the country should follow the scientific development as the guiding ideology in new era. This is of great importance for the management of higher vocational students.

As the core of scientific development, the people-oriented idea takes people's all-round development as the final target. For the student management of higher vocational college, the work should stick to the student oriented principle, arouse students' initiative, enthusiasm and creativity, and promote their self-education, self-management and self-improvement to achieve students' accomplishment and school's training objective. There are two crucial contents for people-oriented management of higher vocational students:

\subsection{The core is people}

People are the subject of world and social development. Fundamentally, the core of harmonious society and scientific development, the most basic and crucial re- 
source of higher vocational college is also the people, and the management of higher vocational college is a system composed of people. The core value of management and development of higher vocational college is the people-oriented concept. In short, people are the center as well as the goal of education, people is the beginning as well as the ending of education, and people are the basis as well as the foundation of education. Emphasis on people's all-round development, individuality and creativity is the basic content of scientific educational idea. Therefore, the campus management must be student- oriented and promote the all-round-development of student.

\subsection{Students are taken as the subject and the object}

Students are taken as the subject and object of student management. Pointed out by the United Nations Educational, Scientific, and Cultural Organization in The Higher Education of the 21st Century: Universal Declaration of Outlook and Action: "apparently, the higher education requires new viewpoint and mode which are centered on students", "deciders of the nation and higher college should take students as their emphasis, view them as the main participant of educational reform of university". It requires our work respect and serve reasonable needs of students' growth.

\section{The problems of present manage- ment of higher vocational students}

It is universal for the higher vocational college that the management is relatively difficult, which are usually demonstrated in the following points:

\subsection{The relatively low quality of high- er vocational students}

Compared with regular colleges, the higher vocational colleges are easier to enter, so these students have relatively poorer basis, lower comprehensive qualities and weaker sense of social responsibility. Meanwhile, many vocational students, who come from rich families, just pay for college study and live a carefree life while others who have poor parents are urgent for part-time job and student loan. Therefore, there is serious division between higher vocational students and they have no enthusiasm for learning.

\subsection{The poor learning culture of higher vocational students}

It is not unusual to find poor learning atmosphere in higher vocational colleges. These unmotivated students have inadequate learning motivation, unclear learning objectives and weak learning conscientiousness. Some students go to vocational college just for the diploma. Consequently, there are quite a few make-up examinations after the term ends. Meanwhile, the wide popularity of computer and internet has brought convenience to students' life and study as well as damage to some students' fine ecology. There are students who go to the internet bar for overnight movie or computer games. Sometimes, they even stay at the internet bar for several days.

\subsection{The mental and physical prob- lems of vocational students}

The long-period of competitive environment aiming at college entrance examination has had positive effects on the mental and physical health of vocational students, especially those with poor academic performance. Some students are rather sensitive, doubtful, contemptuous, irritable, bigoted and hostile. According to survey, there are obsessive-compulsive disorder, depressive disorder and anxiety disorder among vocational students of 20-23 years old. Besides, more and more vocational students are addicted to puppy love, which often cause emotional disputes even contradictions between classes. 


\section{How to carry on the people- oriented management of higher vo- cational students}

Based on the reality of higher vocational students, the implementation of scientific development should deeper into campus construction and student training of higher vocational college, which is the fundamental guarantee for efficient training mechanism and excavating students' potency.

\subsection{To renew management ideas}

According to the scientific development and the people-oriented principle, we integrate the students management of higher vocational college with talent training of students for the realization of the following three transitions:

Firstly, to promote the transition of teaching-oriented to student-oriented. The people-oriented principle should be adhered to from the beginning to the ending in vocational college. All education and management must be launched according to students' interests, focusing on students' development and students' need for growing.

Secondly, to promote the transition of passive management and education to students' initiative and creativity. On the basis of development rules of students, the higher vocational college should respect the individuality and difference of students, safeguard their reasonable demands and interests, train their sense of ownership and encourage them to establish self-evaluation and self-supervision system to realize their self-improvement of comprehensive qualities.

Thirdly, to promote the transition of higher vocational education from single theoretical education to professional talent training and harmonious college and society development. The student management of higher vocational college should focus on talent training, promote the concerted development of theoretical teaching and practical teaching, promote the speedy and fine development of vocational college.

\subsection{To improve management mecha- nism}

The student-oriented management of higher vocational college should guarantee the complete operation mechanism.

Firstly, to follow the school regulation and improve the daily management of students. On the one hand, we should guide students in understanding college regulations and rules, and notify them announcements, like the evaluation criterion of outstanding students, cadres and classes, Putonghua Proficiency Test, and Computer Rank Examination. On the other hand, the management system related to students' life and study must be formulated, for example, the treatment methods of night out, and violation of electrical appliances.

Secondly, to bring up outstanding class leaders and play the leading role of model students. We should fully play the leading role of party members and model students, fulfill students management and cultivate a fine learning atmosphere.

Thirdly, to strengthen students' communication and mental health. On the one hand, we should begin the psychological counseling for problems of daily life, study, employment, and so on, and make efforts to establish a feedback mechanism centered on monitor and tutor. On the other hand, the counseling should be integrated with teaching task to promote the harmonious student-teacher relation and teaching atmosphere.

Fourthly, care for the vulnerable groups and help them to solve difficulties. From entering school, the achieves for needy students should be established and perfected, and corresponding measures be taken to help them with their study and employment, such as the social practice and work-study program. Besides, the 
hand-out of subsidies for impoverished students should be fair and open.

Fifthly, to innovate the thinking of work and improve students' comprehensive quality. On the one hand, group activities can be carried out to guide and improve students' comprehensive quality, and cohesion. On the other hand, focused remedial classes can be carried out to help students with continuing education and employment.

\subsection{To improve the management methods}

The people-oriented management of higher vocational students must be combined with teaching survey and working though innovation for two integrations.

Firstly, to integrate theory with practice. The people-oriented management of higher vocational students should improve educational and management methods, which requires good theoretical teaching in class to improve their professional knowledge and ideological quality and sufficient social practice to enhance their innovative capability.

Secondly, to combine management with service. The people-oriented management of higher vocational students should focus on students, grasp their thinking individuality and consider their different needs to integrate the improvement of students' comprehensive professional quality with the management work of students and establish a sound training and service system for students.

\subsection{To cons truct campus culture}

As the spiritual pillar of higher vocational college's healthy development, the harmonious campus culture is required by the people-oriented development and functions as the efficient and practical way of achieving scientific development.

Firstly, to strengthen the construction of campus material culture. The peopleoriented management of higher vocation- al students supplies harmonious and healthy living and study environment through the construction of campus material culture, such as school motto, bulletin board and blackboard newspaper.

Secondly, to strengthen the construction of campus spiritual culture. The people-oriented management of higher vocational students supplies a spiritual home for students through the construction of campus spiritual culture. The students' sense of honor and cohesion will be enhanced by cultural activities, such as regular class meeting and commendation meeting.

Thirdly, to strengthen the construction of campus regulation culture. The peopleoriented management of higher vocational students guarantees the healthy development of harmonious campus through campus regulation culture. The formulation of management system must be precise, scientific, people oriented and concrete, while the implementation should be strict as well as gentle.

\section{References}

[1] Ren Hongwei, Guo Yujie, "The Construction of Vocational Colleges' Peopleoriented Education Concept,"China Adult Education, pp. 91-92, 2008.

[2] Baicai Keyong, 'Focusing on Students' all-round Development - an Important Educational Idea and Reform," Research in Higher Education, pp. 11-15, 2000.

[3] Wu Huamei, "The Necessity of Peopleoriented Management of Vocational Students,"Modern Business Trade Industry, pp. 278-279, 2008.

[4] Zhang Xin, "How to Construct the People-oriented Educational Idea in Higher Vocational College,"Shaanxi Education, pp. 15, 2009.

[5] Wang Lei, "The Construction of Characteristic Culture of Vocational Col-

lege,"Education and Vocation, pp. 47-48, 2009. 